\title{
FOLIAR APPLICATION OF CALCIUM AND BORON IMPROVES THE SPIKE FERTILY AND YIELD OF WHEAT
}

\author{
APLICAÇÃO FOLIAR DE CÁLCIO E BORO MELHORA A FERTILIDADE DA \\ ESPIGA E PRODUTIVIDADE DO TRIGO
}

\section{Tiago ZOZ ${ }^{1}$; Fábio STEINER ${ }^{2}$; Edleusa Pereira SEIDEL ${ }^{3}$; Deise Dalazen CASTAGNARA ${ }^{4}$; Gabriel Elias de SOUZA}

1. Professor, PhD., Mato Grosso do Sul State University - UEMS, Cassilândia, MS, Brazil. zoz@ uems.br; 2. Professor, PhD., UEMS, Cassilândia, MS, Brazil. steiner@uems.br; 3. Professora, PhD., State University of Western Paraná - UNIOESTE, Marechal Cândido Rondon, PR, Brazil; 4 Professor, PhD., Federal University of Pampa - UNIPAMPA, Uruguaiana, RS, Brazil; 5. Agronomist, Integrated Colleges of Ourinhos - FIO, Ourinhos, SP, Brazil.

\begin{abstract}
Foliar applications of calcium $(\mathrm{Ca})$ and boron $(\mathrm{B})$ could improve the fertilization of flowers and enhance the wheat yield. The effects of foliar spray of $\mathrm{Ca}$ and $\mathrm{B}$ on plant growth, grain yield and yield components of wheat were investigated in this study. Treatments consisted of $0,1.8,3.6$, and $7.2 \mathrm{~L} \mathrm{ha}^{-1}$ application of chelated fertilizer containing $125 \mathrm{~g} \mathrm{~L}^{-1}$ of $\mathrm{Ca}$ and $6 \mathrm{~g} \mathrm{~L}^{-1}$ of $\mathrm{B}$ (Omega Cabor $\mathrm{II}^{\circledR}$ ), divided into two spray, the first one at tillering and the second at early bloom. The results revealed that foliar spray of $\mathrm{Ca}$ and $\mathrm{B}$ did not affect the stem diameter, peduncle length, spike length, hectoliter weight and thousand-grain mass of wheat. Maximum plant height and flag leaf insertion height was recorded with $4.0 \mathrm{~L} \mathrm{ha}^{-1}$ application of foliar fertilizer (4\% increase over control). The $7.2 \mathrm{~L} \mathrm{ha}^{-1}$ application of foliar fertilizer increased significantly the number of spikelets per spike $(9 \%)$, number of grains per spike (24\%), grain mass per spike $(28 \%)$, spike mass $(14 \%)$, number of spikes $\mathrm{m}^{-2}(32 \%)$ and grain yield $(30 \%)$ compared to the control. Foliar application of $\mathrm{Ca}$ and $\mathrm{B}$ improves growth, fertilization of flowers and the number of fertile tillers of wheat plants resulting in higher grain yield.
\end{abstract}

KEYWORDS: Fertilization of flowers, Foliar fertilization. Plant nutrition. Tillering. Triticum aestivum.

\section{INTRODUCTION}

Calcium $(\mathrm{Ca})$ and boron (B) are important nutrients for growth and development of plants and participate in several physiological processes in plants. Calcium is an essential part of the plant cell wall and necessary for new cell formation. It enhances resistance to bacterial and viral diseases (USTEN et al., 2006) and activates several enzyme systems that regulate leaf and root growth (MENGEL; KIRKBY, 2001). Boron contributes to cell wall strength and development, as well as being critical to cell division, fruit and seed development, sugar synthesis and transport, and hormone development (CAMACHO-CRISTÓBAL et al., 2008). Calcium and boron combined are essential to pollen grain germination and pollen tube elongation (KRICHEVSKY et al., 2007), which helps provide successful fertilization or pollination, preventing the abortion of flowers. However, the benefits of $\mathrm{Ca}$ and $\mathrm{B}$ application depend on a balance between $\mathrm{Ca}$ and $\mathrm{B}$ levels in the plant. According to Tariq and Mote (2007), low Ca and high B could be detrimental to plant growth and yield.

Calcium and boron deficiency can occur in very weathered soils due to continuous cropping, soil erosion, leaching of exchangeable bases, reduction of soil organic matter, and adsorption by aluminum and iron (hydr)oxides (STEINER; LANA, 2013; LANA et al., 2013). Boron plays a key role in root function and low B levels reduce the plant's ability to uptake water and nutrients from the soil, which often induces a Ca deficiency (TARIQ; MOTE, 2007). Foliar application of B is preferred over soil application because of the relatively narrow range from deficient to toxic levels (TRAUTMANN et al., 2014). Effectiveness of foliar spray depends on the nutrient uptake rate by leaves and its translocation into the plant (FERNÁNDEZ; BROWN, 2013). Foliar uptake and translocation of nutrient for other plant parts can be influenced positively or negatively by a series of factors, such as source used, plant species, application time. Chelated fertilizers have been developed to increase nutrient utilization efficiency. Calcium and boron applied by the foliar spray is transported in the phloem preferably for new tissues, with the movement linked to metabolic activity of plants.

However, despite the importance of these nutrients, the foliar application of $\mathrm{Ca}$ and $\mathrm{B}$ shows conflicting and inconclusive results. Weaver et al. (1985) found that applications of calcium nitrate and boric acid in common bean, during the opening of the first flowers, promoted higher retention of pods per plant and, consequently, increase in grain yield. 
Significant increases on the grain yield with foliar application of $\mathrm{Ca}$ and $\mathrm{B}$ were also reported for soybean (BEVILAQUA et al., 2002; SOUZA et al., 2008) and for common bean (FARINELLI et al., 2006). On the other hand, Silva et al. (2006) found no effect of foliar fertilization with calcium $(500 \mathrm{~g}$ $\mathrm{ha}^{-1}$ of $\left.\mathrm{Ca}\right)$ and boron $\left(60 \mathrm{~g} \mathrm{ha}^{-1}\right.$ of $\left.\mathrm{B}\right)$ on the yield components and grain yield of common bean. Seidel and Basso (2012) found that 3.0 $\mathrm{L} \mathrm{ha}^{-1}$ application of foliar fertilizer containing $100 \mathrm{~g} \mathrm{~L}^{-1}$ of $\mathrm{Ca}$ and $5 \mathrm{~g}$ $\mathrm{L}^{-1}$ of $\mathrm{B}$ at different growth stages of soybean also did not affect the retention of pods and grain yield of the crop. However, the effect of foliar application of $\mathrm{Ca}$ and $\mathrm{B}$ on the grain yield of wheat (Triticum aestivum L.) are still unknown. Wheat is an important winter cereal crops from Brazil considering its use for food, animal feed or forage, seed industries, and other industrial purposes.

The objective of this study was to investigate the effect of foliar spray of calcium and boron on plant growth, grain yield and yield components of wheat. The hypothesis is that early bloom applications of $\mathrm{Ca}$ and $\mathrm{B}$ could improve the fertilization of flowers and wheat yield.

\section{MATERIAL AND METHODS}

The experiment was carried out in Maripá,

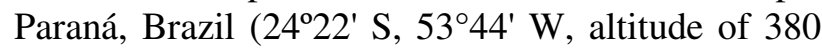

ZOZ, T. et al.

m). The soil was a clayey Rhodic Hapludox (Red Latosol in the Brazilian classification), with $775 \mathrm{~g}$ $\mathrm{kg}^{-1}$ of clay, $125 \mathrm{~g} \mathrm{~kg}^{-1}$ of silt, and $100 \mathrm{~g} \mathrm{~kg}^{-1}$ of sand. Before starting the experiment, soil samples were taken from the surface layer $(0-0.20 \mathrm{~m})$, airdried, sieved through a $2.0 \mathrm{~mm}$ mesh, and analyzed according to Embrapa (2009). Soil chemical analysis showed $\mathrm{pH}$ in $\mathrm{CaCl}_{2} 0.01 \mathrm{~mol} \mathrm{~L}^{-1}$ of $5.0,28$ $\mathrm{g} \mathrm{dm}^{-3}$ of organic matter, $15 \mathrm{mg} \mathrm{dm}^{-3}$ of $\mathrm{P}$ (Mehlich-1), $5.4 \mathrm{cmol}_{\mathrm{c}} \mathrm{dm}^{-3}$ of $\mathrm{H}+\mathrm{Al}, 0.7 \mathrm{cmol}_{\mathrm{c}} \mathrm{dm}^{-}$ ${ }^{3}$ of $\mathrm{K}, 7 \mathrm{cmol}_{\mathrm{c}} \mathrm{dm}^{-3}$ of $\mathrm{Ca}, 1.5 \mathrm{mmol}_{\mathrm{c}} \mathrm{dm}^{-3}$ of $\mathrm{Mg}$, $14.7 \mathrm{cmol}_{\mathrm{c}} \mathrm{dm}^{-3}$ of CEC, $63 \%$ of soil base saturation, $15 \mathrm{mg} \mathrm{dm}^{-3}$ of $\mathrm{Cu}$ (Mehlich-1), $1.8 \mathrm{mg}$ $\mathrm{dm}^{-3}$ of Zn (Mehlich-1), and $0.25 \mathrm{mg} \mathrm{dm}^{-3}$ of B (water heated). The area has been cultivated in notill since 1996 and the area was planted to soybean/maize and soybean/wheat, in the harvests $2006 / 07$ and 2007/08, respectively.

The regional climate, according to Köppen classification, is Cfa, humid subtropical (mesothermal), with warm summers and a tendency towards high rainfall concentration (mean temperature above $22{ }^{\circ} \mathrm{C}$ ) and winter with infrequent frosts (mean temperature below $18{ }^{\circ} \mathrm{C}$ ) with no defined season, and mean annual rainfall of $1,500 \mathrm{~mm}$. Rainfall data during the experiment are shown in Figure 1.

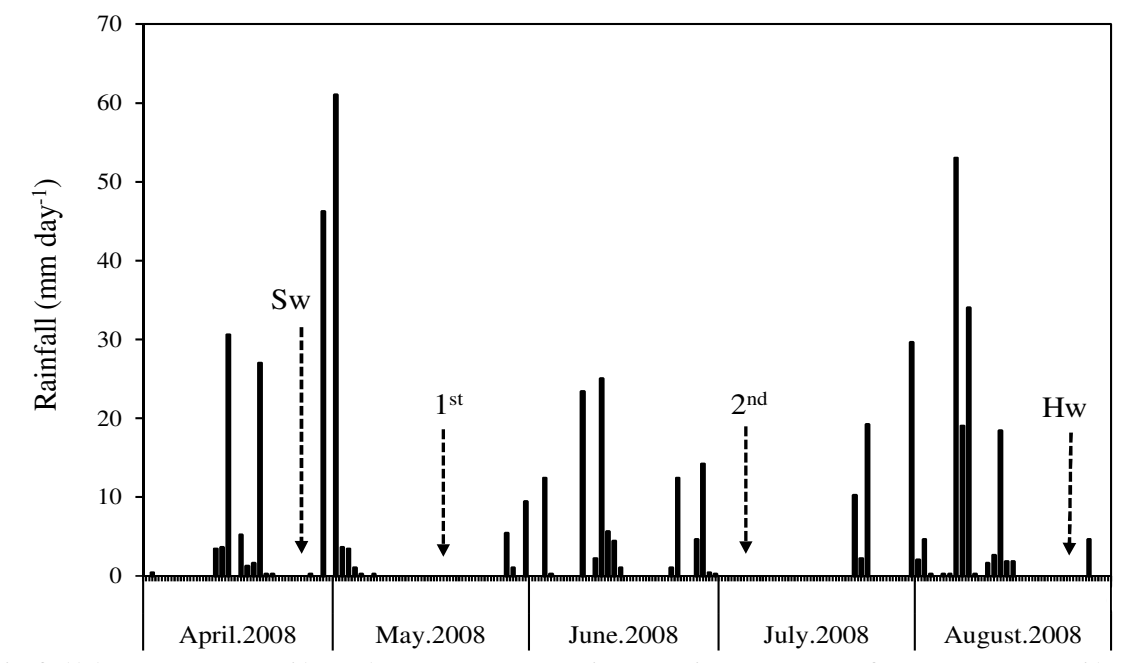

Figure 1. Daily rainfall between April and August 2008 in Maripá, State of Paraná, Brazil. Sw - wheat sowing, $1^{\text {st }}$ and $2^{\text {nd }}-$ first and second foliar spray, respectively, Hw - wheat harvest.

Wheat [Triticum aestivum L., cv. CD 104] was sown on April 26, 2008, in rows $0.15 \mathrm{~m}$ apart at a density of 350 seeds $\mathrm{m}^{-2}$. Fertilization was carried out by applying $20 \mathrm{~kg} \mathrm{ha}^{-1}$ of $\mathrm{N}, 100 \mathrm{~kg} \mathrm{ha}^{-1}$ of $\mathrm{P}_{2} \mathrm{O}_{2}$ and $100 \mathrm{~kg} \mathrm{ha}^{-1}$ of $\mathrm{K}_{2} \mathrm{O}$ at sowing, and $80 \mathrm{~kg} \mathrm{ha}^{-1}$ of $\mathrm{N}$ topdressing at the beginning of plants's tillering as urea. Pests and diseases control was carried out with two applications of methamidophos (120 g a.i. $\left.\mathrm{ha}^{-1}\right)$, lufenuron $\left(5 \mathrm{~g}\right.$ a.i. $\left.\mathrm{ha}^{-1}\right)$ and azoxystrobin + cyproconazole $\left(60 \mathrm{~g}\right.$ a.i. $\mathrm{ha}^{-1}+24 \mathrm{~g}$ a.i. $\left.\mathrm{ha}^{-1}\right)$.

The experimental design was randomized blocks with five replications. Treatments consisted of four rates of Omega Cabor $\mathrm{II}^{\circledR}$ chelated fertilizer (125 $\mathrm{g} \mathrm{Ca} \mathrm{L}^{-1}$ and $6 \mathrm{~g} \mathrm{~B} \mathrm{~L}^{-1}$ ), divided into two spray, 
the first at tillering (18 days after plants emergence) and second at early bloom (65 days after plants emergence). The rates used were: (1) control (without spray); (2) $1.8 \mathrm{~L} \mathrm{ha}^{-1}$ of foliar fertilizer (225 g ha ${ }^{-1}$ of $\mathrm{Ca}+10.8 \mathrm{~g} \mathrm{ha}^{-1}$ of B); (3) $3.6 \mathrm{~L} \mathrm{ha}^{-1}$ of foliar fertilizer $\left(450 \mathrm{~g} \mathrm{ha}^{-1}\right.$ of $\mathrm{Ca}+21.6 \mathrm{~g} \mathrm{ha}^{-1}$ of B); and (4) $7.2 \mathrm{~L} \mathrm{ha}^{-1}$ of foliar fertilizer $\left(900 \mathrm{~g} \mathrm{ha}^{-1}\right.$ of $\mathrm{Ca}+43.2 \mathrm{~g} \mathrm{ha}^{-1}$ of $\left.\mathrm{B}\right)$. The rates corresponded to $50 \%, 100 \%$ and $200 \%$ of the recommended rate $(3.6$ $\mathrm{L} \mathrm{ha}{ }^{-1}$ ) for the wheat crop. Applications were performed with a $\mathrm{CO}_{2}$ pressurized sprayer with 0.8 MPa working pressure capacity, equipped with flat fan nozzle, adjusted to apply $165 \mathrm{~L} \mathrm{ha}^{-1}$ broth. The plants were sprayed at dusk due to a lower likelihood of drift by wind speed reduction and higher relative humidity. After spray, a minimum period of 72 hours without rain was observed, enabling the best use of the product. Each experimental plot consisted of eight $6.0 \mathrm{~m}$ long rows, considering the six central lines as floor area, ignoring $1.0 \mathrm{~m}$ from the ends of each row.

Wheat was harvested when it reached physiological ripeness. Agronomic characteristics of the crop were assessed against the following variables: plant height, flag leaf insertion height, stem diameter, peduncle length, spike length, number of spikelets per spike, number of grains per spike, spike mass, grain mass per spike, number of spikes per square meter, hectoliter weight (HW), thousand grain mass and grains yield corrected to $130 \mathrm{~g} \mathrm{~kg}^{-1}$ water content.

Data were submitted to analysis of variance and regression, both at the 0.05 level of confidence
ZOZ, T. et al.

by $\mathrm{F}$ test. The significant equations with the higher coefficient of determination were adjusted. All analyses were performed using SigmaPlot 11.0 software for Windows (Systat Software, Inc., San Jose, CA, USA).

\section{RESULTS AND DISCUSSION}

Foliar application of calcium and boron did not affect the stem diameter, peduncle length and spike length. The stem diameter, peduncle length and spike length were $3.90 \pm 0.24 \mathrm{~mm}, 15.1 \pm 1.80 \mathrm{~cm}$, $8.92 \pm 2.08 \mathrm{~cm}$, respectively. These agronomic characteristics are predominantly determined by genetic factors, intrinsic to the cultivar, being little affected by environmental factors. The hectoliter weight and thousand grain mass of wheat were also not affected by foliar application of $\mathrm{Ca}$ and $\mathrm{B}$. Hectoliter weight and thousand grain mass were $79.6 \pm 0.8 \mathrm{~g}$ and $46.2 \pm 4.2 \mathrm{~g}$, respectively.

The plant height and flag leaf insertion height increased significantly with foliar application of $\mathrm{Ca}$ and $\mathrm{B}$ (Figure 2). The maximum plant height $(82.6 \mathrm{~cm})$ and flag leaf insertion height $(60.0 \mathrm{~cm})$ were recorded with the $4.0 \mathrm{~L} \mathrm{ha}^{-1}$ application of foliar fertilizer. Kappes et al. (2008) reported similar results for soybean crop, who found that foliar application of $\mathrm{B}$ increased the mean plant height. This increase in plant height of wheat with the $\mathrm{Ca}$ and $\mathrm{B}$ application is related to the functions of these nutrients on several physiological processes in the plants.

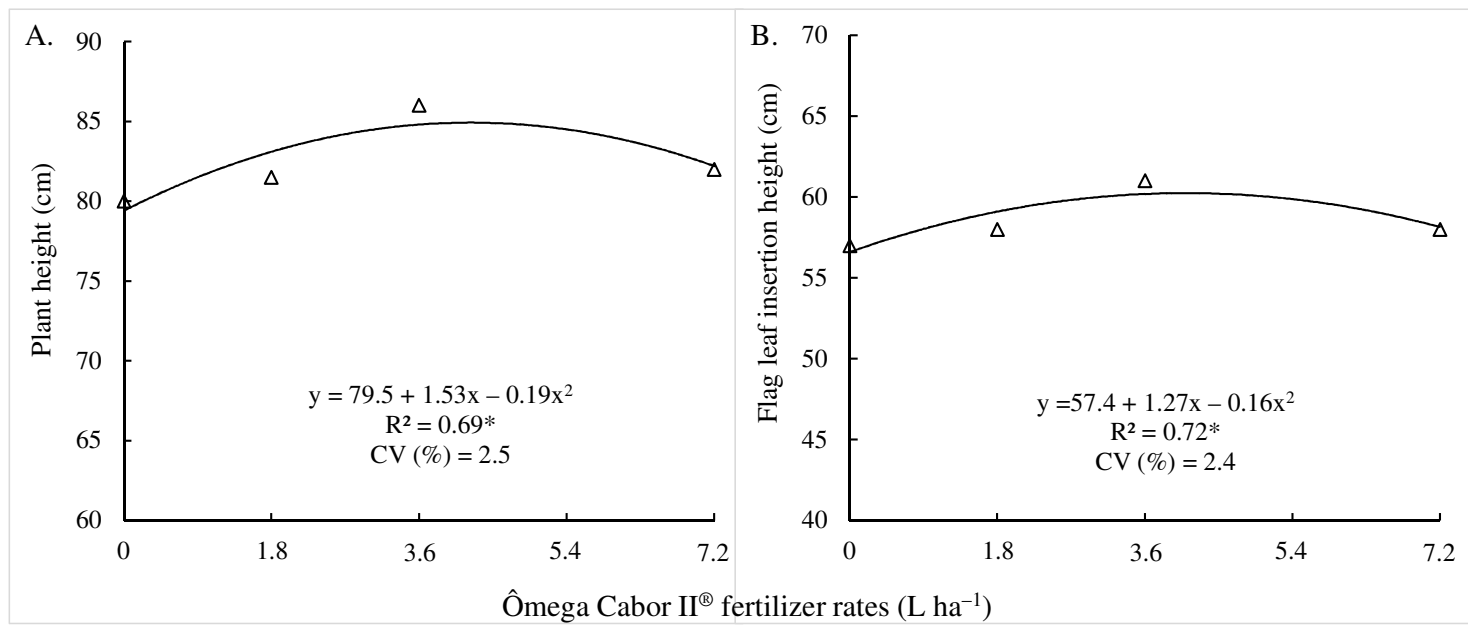

Figure 2. Effect of foliar spray of Omega Cabor $\mathrm{II}^{\circledR}$ chelated fertilizer $\left(125 \mathrm{~g} \mathrm{~L}^{-1}\right.$ of Ca and $6 \mathrm{~g} \mathrm{~L}^{-1}$ of $\left.\mathrm{B}\right)$ on the plant height (A) and flag leaf insertion height (B) of wheat (Triticum aestivum L.). *: statistical significance at $5 \%$ by $\mathrm{F}$ test. $\mathrm{CV}$ : coefficient of variation.

Calcium participates as messenger in metabolic processes related to growth and development of plants, such as cell division, differentiation and elongation (HEPLER, 2005), and 
activate several enzyme systems that regulate leaf and root growth (MENGEL; KIRKBY, 2001). In turn, the B is essential for cell wall formation and it plays an important role in the development and growth of new cells (CAMACHO-CRISTÓBAL et al., 2008). In addition, this element also regulates the production of auxin in the plants. Auxin is a plant hormone that among other functions is responsible for elongation and cell division and growth of the plant (MENGEL; KIRBY, 2001). Therefore, the adequate supply of $\mathrm{Ca}$ and $\mathrm{B}$ is very important for growth and development of plants.

The number of spikelets per spike and number of grains per spike increased progressively with increasing rates of foliar fertilizer containing $125 \mathrm{~g} \mathrm{~L}^{-1}$ of $\mathrm{Ca}$ and $6 \mathrm{~g} \mathrm{~L}^{-1}$ of $\mathrm{B}$ (Figure $3 \mathrm{~A}$ and 3B). The number of spikelets per spike increased from 17.8 units in the control to a maximum of 19.5 units with $7.2 \mathrm{~L} \mathrm{ha}^{-1}$ application of foliar fertilizer, indicating mean increase of $9 \%$ (Figure 3A). The number of grains per spike increased from 43.9 units in the control to a maximum of 54.6 units with 7.2 $\mathrm{L} \mathrm{ha}^{-1}$ application of foliar fertilizer, indicating mean increase of 24\% (Figure 3B). This increase in the number of grains per spike indicates that the $\mathrm{Ca}$ and $\mathrm{B}$ application improved the fertilization of flowers, reducing the abortion of flowers. Weaver et al. (1985) found that foliar application of Ca and B resulted in higher retention of pods per plant of common bean. Similarly, Tahir et al. (2009) also found that foliar B application at different growth stages increased the number of grains per spike of wheat. Calcium and boron deficiency can interfere in the germination of pollen grains and growth of pollen tubes (KRICHEVSKY et al., 2007), resulting in the reduction of the number of grains per spike. According to Rosolem et al. (1990), there is high negative correlation between the $\mathrm{Ca}$ concentration in the plant and number of flowers or pods aborted. Tahir et al. (2009) reported that B deficiency impairs grain setting in wheat, resulting in increased number of open spikelets and decreased number of grains per spike.

Foliar application of $\mathrm{Ca}$ and $\mathrm{B}$ resulted in significant increase of the grain mass per spike and spike mass of wheat. The grain mass per spike and spike mass increased from 1.42 and $3.48 \mathrm{~g}$ in the control treatment to a maximum of 1.82 and $3.98 \mathrm{~g}$ with $7.2 \mathrm{~L} \mathrm{ha}^{-1}$ application of foliar fertilizer, indicating mean increase of 28 and $14 \%$, respectively (Figure 3C and 3D). The increase in the grain mass per spike and spike mass was due to increased number of grains per spike obtained with to the foliar fertilizer rates (Figure 3B).
The number of spikes per unit area was affected by foliar application of $\mathrm{Ca}$ and $\mathrm{B}$ (Figure $3 \mathrm{E})$. The number of wheat spikes per unit area increased from 228 spikes $\mathrm{m}^{-2}$ in the control treatment to a maximum of 301 spikes $\mathrm{m}^{-2}$ with 7.2 $\mathrm{L} \mathrm{ha}{ }^{-1}$ application of foliar fertilizer, indicating mean increase of $32 \%$. The increase in the number of spikes per unit area was due to the higher number of fertile tillers per plant at the end of crop cycle. Ahmad and Irshad (2011) verified that B application increased in $15 \%$ the number of tillers per plant of wheat.

The reason for increased number of tillers per plant seems to be presence and utilization of $\mathrm{B}$ at required stages of plant growth. Boron insufficiency may results in retarded growth, increase in aborted tillers, and suppressed grain yield per tiller (TAHIR et al., 2009). Boron deficiency in cereals may reduce the number of tillers per plant mainly because it makes the thinner stems and shorter and fewer tillers (DUNN et al, 2005). The number of fertile tillers are very important to wheat crops because the higher number of fertile tillers per area, the higher grain yield. Number of fertile tillers in wheat is more important instead of total number of tillers because the increase in yield is only determined due to increase in fertile tillers (TAHIR et al., 2009). Effect of B application on fertile tillers are in agreement with those reported by Khan et al. (2006) and Ahmad and Irshad (2011), who showed that B application had significant effect on fertile tillers of rice and wheat, respectively.

The grain yield of wheat increased progressively with increasing rates of foliar fertilizer (Figure 3F). The percentage increase of grain yield was $30 \%$, when comparing the wheat yield without foliar spray $\left(2,037 \mathrm{~kg} \mathrm{ha}^{-1}\right)$ and with $7.2 \mathrm{~L} \mathrm{ha}^{-1}$ application of foliar fertilizer $\left(2,650 \mathrm{~kg} \mathrm{ha}^{-1}\right)$. There was mean increase of $85 \mathrm{~kg} \mathrm{ha}^{-1}$ of wheat grains for each liter per hectare of foliar fertilizer applied. The higher grain yield of wheat with foliar application of $\mathrm{Ca}$ and $\mathrm{B}$ was due to the increased in the number of grains per spike (Figure 3B) and number of spikes per unit area (Figure 3E), provided by the increased in the fertilization of flowers and number of fertile tillers per plant, respectively.

Positive effects of $\mathrm{Ca}$ and $\mathrm{B}$ application on grain yield are in agreement with those reported by Souza et al., (2008), Farinelli et al. (2006), Bevilaqua et al. (2002), and Weaver et al. (1985), who found that foliar application of $\mathrm{Ca}$ and $\mathrm{B}$ increased the grain yield of soybean and common bean crops. On the other hand, Seidel and Basso (2012) and Silva et al. (2006) found no effect of 
foliar fertilization of $\mathrm{Ca}$ and $\mathrm{B}$ on the yield components and grain yield of soybean and common bean, respectively. Effects of foliar application of $\mathrm{Ca} \mathrm{B}$ on grain yield are related to the availability of these nutrients in the soil. In this study, the levels of available $\mathrm{Ca}\left(7.0 \mathrm{cmol}_{\mathrm{c}} \mathrm{dm}^{-3}\right.$ of Ca) and $\mathrm{B}\left(0.25 \mathrm{mg} \mathrm{dm}^{-3}\right.$ of $\left.\mathrm{B}\right)$ in the soil were in the availability classes high and medium, respectively (RAIJ et al., 1997).
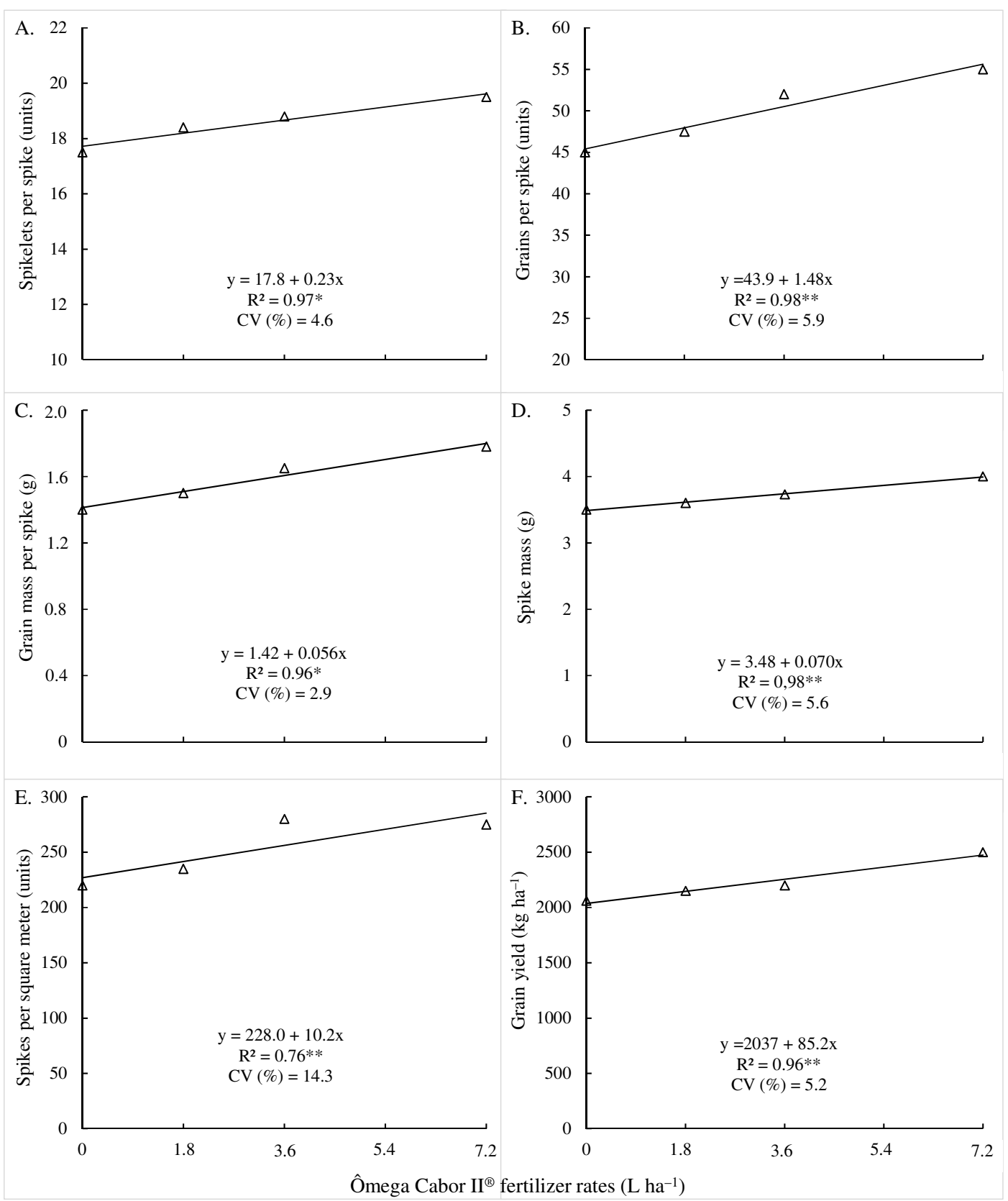

Figure 3. Effect of foliar spray of Omega Cabor $\mathrm{II}^{\circledR}$ chelated fertilizer $\left(125 \mathrm{~g} \mathrm{~L}^{-1}\right.$ of Ca and $6 \mathrm{~g} \mathrm{~L}^{-1}$ of $\left.\mathrm{B}\right)$ on the number of spikelets per spike (A), number of grains per spike (B), grain mass per spike (C) spike mass (D), number of spikes per square meter (E) and grain yield (F) of wheat (Triticum aestivum L.). $*$ and $* *$ : statistical significance at $5 \%$ and $1 \%$, respectively, by $\mathrm{F}$ test. $\mathrm{CV}$ : coefficient of variation.

In general, the results presented here confirm the hypothesis established initially and suggest that early bloom applications of $\mathrm{Ca}$ and $\mathrm{B}$ are key components of pollen tube elongation that help ensure more successful fertilization of flowers and higher wheat yields. In this study, the improvement in fertilization of the wheat flowers was evidenced by the increase in the number of 
spikelets per spike, number of grains per spike, grain mass per spike and spike mass (Figure 3). Another important yield component for the increase in grain yield of wheat reported in this study was the number of fertile tillers per area (Figure 3E), which determines the amount of spikes harvested per area.

\section{CONCLUSION}

Foliar application of calcium and boron improves growth, fertilization of flowers and the number of fertile tillers of wheat plants resulting in increased grain yield.

RESUMO: A aplicação foliar de cálcio $(\mathrm{Ca})$ e boro $(\mathrm{B})$ pode garantir a fertilização das flores e aumentar a produtividade do trigo. Este estudo teve como objetivo avaliar o efeito da aplicação foliar de Ca e B no crescimento, nos componentes de rendimento e na produtividade do trigo. Os tratamentos constituíram da aplicação de 0;1,8; 3,6 e 7,2 L $\mathrm{ha}^{-1}$ de fertilizante foliar, na forma de quelato, contendo $125 \mathrm{~g} \mathrm{~L}^{-1}$ de Ca e $6 \mathrm{~g} \mathrm{~L}^{-1}$ de B (Omega Cabor II ${ }^{\circledR}$ ), divididas em duas aplicações foliares, a primeira no início do afilhamento e a segunda no emborrachamento. Os resultados revelaram que a aplicação foliar de Ca e B não afetaram o diâmetro de colmo, comprimento do pedúnculo, comprimento da espiga, peso do hectolitro e massa de mil grãos de trigo. A maior altura de planta e altura de inserção da folha bandeira foram verificados com a aplicação de $4.0 \mathrm{~L} \mathrm{ha}^{-1}$ de fertilizante foliar (aumento de $4 \%$ em relação ao controle). A aplicação de 7.2 $\mathrm{L} \mathrm{ha}^{-1}$ de fertilizante foliar aumentou significativamente o número de espiguetas por espiga (9\%), número de grãos por espiga (24\%), massa de grãos por espiga (28\%), massa de espiga (14\%), número de espigas $\mathrm{m}^{-2}(32 \%)$ e produtividade de grãos (30\%). A aplicação foliar de cálcio e boro melhora o crescimento, a fertilização das flores e o número de afilhos férteis das plantas de trigo resultando no aumento de produção de grãos. aestivum

PALAVRAS-CHAVE: Fertilização das flores. Adubação foliar. Nutrição de planta. Afilhamento. Triticum

\section{REFERENCES}

AHMAD, R.; IRSHAD, M. Effect of boron application time on yield of wheat, rice and cotton crop in Pakistan. Soil \& Environment, Faisalabad, v. 30, n. 1, p. 50-57, jun. 2011.

BEVILAQUA, G. A. P.; SILVA FILHO, P. M.; POSSENTI, J. C. Aplicação foliar de cálcio e boro e componentes de rendimento e qualidade de sementes de soja. Ciência Rural, Santa Maria, v. 32, n. 1. p. 31-34, fev. 2002. http://dx.doi.org/10.1590/S0103-84782002000100006

CAMACHO-CRISTÓBAL, J. J.; REXACH, J.; GONZÁLES-FONTES, A. Boron in plants: deficiency and toxicity. Journal of Integrative Plant Biology, Beijing, v. 50, n. 10, p. 1247-1255, oct. 2008. http://dx.doi.org/10.1111/j.1744-7909.2008.00742.x

DUNN, D.; STEVENS, G.; KENDIG, A. Boron fertilization of rice with soil and foliar applications. 2005. http://plantsci.missouri.edu/deltacrops/pdfs/RiceBoron.pdf <Acesso em 21 Sept. 2014>.

EMBRAPA - Empresa Brasileira de Pesquisa Agropecuária. Manual de análises químicas de solos, plantas e fertilizantes. 2. Ed. Brasília: Informação Tecnológica, 2009. 628p.

FARINELLI, R.; PENARIOL, F. G.; SOUZA, F. S.; PIEDADE, A. R.; LEMOS, L. B. Características agronômicas e qualidade fisiológica de sementes de cultivares de feijão adubados via foliar com cálcio e boro. Científica, Jaboticabal, v. 34, n. 1, p. 59-65, jan./mar. 2006.

FERNÁNDEZ, V.; BROWN, P. H. From plant surface to plant metabolism: the uncertain fate of foliar-applied nutrients. Frontiers in Plant Science, Melbourne, v. 4, n. 1, p. 1-5, jul. 2013.

http://dx.doi.org/10.3389/fpls.2013.00289

HEPLER, P. K. Calcium: A central regulator of plant growth and development. The Plant Cell, Rockville, v. 17, n. 10, p. 2142-2155, aug. 2005. http://dx.doi.org/10.1105/tpc.105.032508 
KAPPES, C.; GOLO, A. L.; CARVALHO, M. A. C. Doses e épocas de aplicação foliar de boro nas características agronômicas e na qualidade de sementes de soja. Scientia Agraria, Curitiba, v. 9, n. 4, p. 291297, jul./set. 2008. http://dx.doi.org/10.5380/rsa.v9i3.11563

KHAN, R.; GURMANI, A. H.; GURMANI, A. R.; ZIA, M. S. Effect of boron application on rice yield under wheat rice system. International Journal of Agriculture and Biology, Faisalabad, v. 8, n. 6, p. 805-808, jun. 2006.

KRICHEVSKY, A.; KOZLOVSKY, S. V.; TIAN, G. W.; CHEN, M.-H.; ZALTSMAN, A.; CITOVSKY, V. How pollen tubes grow. Developmental Biology, Pasadena, v. 303, n. 12, p. 405-420, mar. 2007.

http://dx.doi.org/10.1016/j.ydbio.2006.12.003

LANA, M. C.; STEINER, F.; ZOZ, T.; FRANDOLOSO, J. F.; FEY, R. Prediction of boron adsorption on some soils of State Paraná, Brazil. Semina. Ciências Agrárias, Londrina, v. 34, p. 603-614, mar./abr. 2013. http://dx.doi.org/10.5433/1679-0359.2013v34n2p603

MENGEL, K.; KIRBY, E. A. Principles of plant nutrition. Bern: International Potash Institute, 2001. 687p. http://dx.doi.org/10.1007/978-94-010-1009-2

RAIJ, B Van; CANTARELLA, H.; QUAGGIO, J. A.; FURLANI, A. M. C. Interpretação de resultados de análise de solo. In: RAIJ, B VAN; CANTARELLA, H.; QAUGGIO, J. A.; FURLANI, A. M. C. (Eds.). Recomendações de adubação e calagem para o Estado de São Paulo. 2 ed. Campinas: Instituto Agronômico, 1997. p. 8-13. (Boletim Técnico, 100).

ROSOLEM, C. A.; BOARETTO, A. E.; NAKAGAWA, J. Adubação foliar do feijoeiro. VIII. Fontes e doses de cálcio. Científica, Jaboticabal, v. 18, n. 2, p. 81-86, jan./jun. 1990.

SEIDEL, E. P.; BASSO, W. L. Adubação foliar a base de cálcio e boro no cultivo da soja (Glycine max). Scientia Agraria Paranaensis, Marechal Cândido Rondon, v. 11, n. 2, p. 75-81, abr./jun. 2012.

SILVA, T. R. B.; SORATTO, R. P.; BÍSCARO, T.; LEMOS, L. B. Aplicação foliar de boro e cálcio no feijoeiro. Científica, Jaboticabal, v. 34, n. 1, p. 46-52, jan./mar. 2006.

SOUZA, L. C. D.; SÁ, M. E.; CARVALHO, M. A. C.; SIMUDI, H. M. Produtividade de quatro cultivares de soja em função da aplicação de fertilizante mineral foliar a base de cálcio e boro. Revista de Biologia e Ciências da Terra, Campina Grande, v. 8, n. 2, p. 37-44, jul./dez. 2008.

STEINER, F.; LANA, M. C. Effect of pH on boron adsorption in some soils of Paraná, Brazil. Chilean Journal of Agricultural Research, Chillán, v. 73, n. 2, p. 181-186, apr./jun. 2013.

http://dx.doi.org/10.4067/s0718-58392013000200015

TAHIR, M; TANVEER, A.; SHAH, T. H.; FIAZ, N.; WASAYA, A. Yield response of wheat (Triticum aestivum L.) to boron application at different growth stages. Pakistan Journal of Life and Social Sciences, Oxfordshire, v. 7, n. 1, p. 39-42, jan. 2009.

TARIQ, M.; MOTE, C. J. B. Calcium-boron interaction in radish plants grown in sand culture. Pakistan Journal of Agricultural Sciences, Faisalabad, v. 44, n. 1, p. 123-129, jan./mar. 2007.

TRAUTMANN, R. R.; LANA, M. C.; GUIMARÃES, V. F.; GONÇALVES JUNIOR, A. C.; STEINER, F. Potencial de água do solo e adubação com boro no crescimento e absorção do nutriente pela cultura da soja. Revista Brasileira de Ciência do Solo, Viçosa, v. 38, n. 2, p. 240-251, mar./abr. 2014.

USTEN, N.; ALTUNLU, H.; YOKAS, I.; SAYGILI, H. Influence of potassium and calcium level on severity of tomato pith necrosis and yield of greenhouse tomatoes. Acta Horticulturae (ISHS), Belgium, v. 808, p. 347-350, 2006. 
Foliar application of calcium and boron...

ZOZ, T. et al.

WEAVER, M. L.; TIMM, H.; NAG, H.; BURKE, D. W.; SILBERNAGEL, M. J.; FOSTER, K. Pod retention and seed yield of beans in response to chemical foliar applications. HortScience, Virginia, v. 20, n. 3, p. 429431, may/jun. 1985. 